\title{
Tongue Lipoma
}

National Cancer Institute

\section{Source}

National Cancer Institute. Tongue Lipoma. NCI Thesaurus. Code C7734.

A benign adipose tissue neoplasm of the tongue. 